\title{
KEJUJURAN SALAH SATU PENDONGKRAK PENDIDIKAN KARAKTER DI SEKOLAH \\ Oleh
}

Fadillah $^{1}$

\begin{abstract}
Abstrak : Kejujuran sebagai suatu nilai, seharusnya tidak lagi dipandang sebagai harga material, yang hanya sebatas kebutuhan hidup saja, tetapi menjadi harga yang immaterial, sehingga telah menjadi esensi hidup yang akan melekat pada diri, yang tidak lekang oleh kondisi dan waktu. Hal ini akan ditunjukkan bahwa seseorang yang telah menghayati nilai kejujuran akan terdorong untuk bersikap dan bertindak jujur kepada orang lain bahkan terhadap dirinya sendiri, karena pada dirinya telah tertanam sistem nilai dan keyakinan sistem, yang mengharuskannya untuk berperilaku jujur.

Menyikapi secara kritis, begitu pentingnya

menumbuhkembangkan nilai kejujuran, karena merupakan

konsekuensi logis dari keberadaan (eksistensi) serta hakikat manusia sebagai makhluk sosial dan makhluk berbudaya, yang dapat dilakukan melalui pendidikan.

Membangun karakter melalui pendidikan, tidak hanya pada tataran konsep tetapi mampu dicerna untuk dapat diaplikasikan dalam kehidupan . Dengan demikian akan tumbuh pribadi yang mandiri yang tidak menggantungkan hidup dari pihak atau individu lain. Dan ini perlu dilakukan sejak dini. Jika peserta didik, tak dibangun karakternya, maka yang akan menjadi pemimpin di masa depan nanti, adalah individu-individu yang mudah tunduk pada kepentingan-kepentingan individu atau kelompok lain yang memiliki kepentingan ,yang bisa berakibat negatif dan fatal.
\end{abstract}

\section{Kata kunci : Kejujuran, karakter}

\section{Pengantar}

Sekolah adalah suatu komunitas masyarakat terpelajar. Di dalamnya terjadi hubungan dialogis, banyak arah antara Kepala Sekolah dengan guru, Kepala Sekolah dengan peserta didik, Kepala Sekolah dengan personil sekolah lainnya, guru dengan personil sekolah lainnya, guru dengan peserta

\footnotetext{
${ }^{1}$ Fadillah : Dosen Jurusan Ilmu Pendidikan FKIP Universitas Tanjungpura
} 
didik, antar peserta didik. Sedemikian banyak hubungan dialogis tersebut, memungkinkan pembinaan nilai kejujuran dilakukan dengan sangat efektif. Pembinaan nilai kejujuran di kalangan peserta didik menjadi hal yang urgen . Hal ini untuk menangkis persoalan moral yang menjadi krusial saat ini, dan melanda umat hari ini, menerobos hingga ke segenap lapisan masyarakat dan semua bidang kehidupan. Kejujuran menjadi salah satu sifat dan karakter jiwa yang sangat diperlukan, meskipun menunjukan fenomena yang menjadi langka saat ini, yakni dengan hilangnya semangat kejujuran dalam berbagai lini kehidupan, baik krisis terhadap nilai maupun krisis perbuatan atau perilaku.

Di sekolah, menjadi tugas guru untuk mengajarkan, mencontohkan, membiasakan, membina nilai kejujuran pada peserta didik, jika tidak ingin bangsa ini mengalami kehancuran, sebagaimana yang dikatakan oleh Thomas Lickona (2008, 29), bahwa 'salah satu tanda kehancuran bangsa adalah membudayanya ketidak jujuran'.

\section{Apa yang dimaksud dengan nilai kejujuran?,}

Kejujuran diartikan sifat keadaan jujur, ketulusan hati, dan kelurusan hati, yang dapat dilihat dan diukur melalui perilaku. Jujur adalah melakukan apa yang dikatakan serta mengatakan apa yang dilakukan. Menurut Kamus Besar Bahasa Indonesia (2005), jujur berarti lurus hati tidak berbohong, tidak curang, tulus, dan ikhlas.

Seseorang yang telah menghayati nilai kejujuran akan terdorong untuk bersikap dan bertindak jujur kepada orang lain bahkan terhadap dirinya sendiri, karena pada dirinya telah tertanam sistem nilai dan keyakinan sistem, yang mengharuskannya untuk berperilaku jujur. Bahwa nilai jujur tidak lagi dipandang sebagai harga material, yang hanya sebatas kebutuhan hidup saja. Tetapi nilai jujur sudah menjadi harga yang immaterial, sehingga telah menjadi esensi hidup yang akan melekat pada diri, yang tidak lekang oleh kondisi dan waktu.

Menyikapi secara kritis, begitu pentingnya menumbuhkembangkan nilai kejujuran, karena merupakan konsekuensi logis dari keberadaan (eksistensi) serta hakikat manusia sebagai makhluk sosial dan makhluk berbudaya. Sebagai makhluk sosial dan makhluk yang berbudaya, manusia berada pada jaringan interaksi interdependensi dengan sesama manusia yang diatur dalam pola-pola jaringan norma yang dijabarkan dari nilai yang hidup 
serta beroperasi di satu kelompok masyarakat. Dalam hubungan sesama manusia, kejujuran yang melekat pada masing-masing pribadi akan menjadikan diri tenang, karena tidak jujur akan mengantar pada kegelisahan. Kejujuran juga membawa keberkahan. Demikian juga akan menjadi pangkat segala kebaikan. Kebaikan mengantar manusia pada kebenaran. Plato yang dilandasi oleh gurunya Socrates, menyatakan bahwa kebenaran sering terpenjara oleh badan yang selalu diliputi nafsu. Karenanya manusia perlu menyadari dan mengendalikan nafsunya, agar kembali pada jalan yang benar.

Sistem pendidikan berpedoman pada seperangkat aturan dan pengaturan, guna menegakkan kebenaran yang memang dirancang demi pendekatan sistemik dan bukan untuk disiasati melalui pendekatan perseorangan. Karenanya sistem pendidikan hendaknya mnenempatkan nilai kejujuran sebagai core dari pendidikan.

Sebagai core pendidikan, Praktiknya,(1997: 96), dalam http://www.parisada., mengenalkan dua model pendekatan, yakni Pertama :pendekatan strukturkuantitatif, yang menitikberatkan pada satuan subjek dan jam belajar. Kedua, pendekatan fungsional kualitatif, yaitu menitikberatkan pada substansi kegiatan belajar mengajar sebagai wahana proses alih nilai Pendekatan pertama biasanya mengusulkan adanya mata pelajaran khusus dan jam pelajaran memadai, sementara pendekatan yang kedua lebih pada intensitas pendidikan nilai pada setiap mata pelajaran yang ada secara integratif dan proporsional.

Terlepas dari kontroversi kedua pendekatan tersebut, untuk konteks pendidikan dasar dan menengah yang jumlah subyek dan jam belajarnya yang sudah padat, maka pendekatan kedua lebih cocok dalam rangka validasi pendidikan nilai dalam wahana sekolah, sehingga pembinaan nilai terintegrasi pada seluruh mata pelajaran yang ada di sekolah, karena memang nilai ini menyentuh dunia afektif manusia.

Demikian pula hasil pemikiran dari Konferensi Bersama UPI-UPSI (Universiti Pendidikan Sultan Idris), pada pertengahan Oktober 2010, dengan tema Profesionalisme Guru dalam membangun karakter dan budaya bangsa, salah satunya menunjuk bahwa pendidikan karakter tidak perlu diberikan dalam mata pelajaran tersendiri, melainkan diintegrasikan dengan mata pelajaran lain.

Di Mesir, sebagaimana yang diungkapkan oleh Prof.Dr.Kawsar H.Kouchok, dalam penyajiannya pada The Global Meeting of Experts on 
Teaching for tolerance and Freedom of religion or belief, tanggal 2 September 2004 di Oslo, pendidikan moral dan nilai juga diintegrasikan pada semua mata pelajaran, di samping adanya kursus atau pelatihan khusus pendidikan nilai dan moral, yang dikelola Departemen Pendidikan Mesir.

Dengan demikian, kiranya hal ini perlu disadari oleh personil sekolah, bahwa pembinaan nilai kejujuran pada mata pelajaran merupakan upaya pengintegrasian pendidikan nilai ke dalam mata pelajaran yang ada di sekolah

\section{Apa yang dimaksud dengan pendidikan karakter ?}

Pendidikan karakter adalah sebuah usaha sadar untuk mendidik peserta didik agar dapat mengambil keputusan dengan bijak dan memperhatikannya dalam kehidupan sehari-hari, sehingga mereka dapat memberikan kontribusi yang positif kepada lingkungannya. Dalam pasal 1 (1) UU No.20/2003, dikatakan bahwa "proses pembelajaran sebagai wahana pendidikan dan pengembangan karakter yang tak terpisahkan dari pengembangan kemampuan sains, teknologi dan seni “.

Pada pasal 1 (3) dan pasal 3 UU No.20/2003 bicara 'landasan legal formal akan keharusan membangun karakter bangsa melalui upaya pendidikan.'

Proses pendidikan yang secara mikro terwujud dalam proses pembelajaran, harus dibangun sebagai proses transaksi kultural yang harus mengembangkan karakter sebagai bagian yang terintegrasi dari pengembangan sains, tehnologi dan seni, dan tidak terjebak pada proses pendidikan di tingkat tujuan individual

Dengan dasar UU ini maka tanggung jawab membangun karakter menjadi tanggung jawab bersama, baik orang tua, guru di sekolah ataupun masyarakat yang mengakar pada nilai-nilai luhur bangsa. Pewarisan dengan cara penggalian nilai-nilai budaya yang dimiliki bangsa membawa kita mendidik dengan tidak melupakan budaya sendiri. UPI mengistilahkan dengan etno paedagogi. Beragamnya suku bangsa Indonesia, tentunya akan beragam pula nilai-nilai luhur setiap suku bangsa, namun kita disatukan oleh nilai luhur yang sama seperti yang terkandung dalam Pancasila, yakni 1) nilai ke-tuhan-an, yang menunjukkan bangsa yang mengakui adanya Tuhan yang Esa, meskipun berada di lingkungan masyarakat yang beragam agama, namun saling menghargai dan menghormati satu sama lain.; 2) nilai keberadaban , mengakui bahwa bangsa adalah makhluk yang beradab, memiliki norma-norma yang mengatur kehidupan; 3) nilai persatuan, meskipun Indonesia terdiri dari beragam suku bangsa, namun kita selalu 
dipersatukan dengan semangat kebangsaan sebagai bangsa Indonesia, sesuai dengan semboyan Bhinneka Tunggal Ika; 4) nilai musyawarah. Dalam menyelesaikan masalah bangsa Indonesia dapat menyelesaikannya dengan musyawarah; 5) nilai keadilan, yang membawa kita untuk selalu bersikap adil dimanapun berada dan kapanpun waktunya.

Dengan penggalian serta pewarisan nilai-nilai yang terkandung dalam Pancasila, akan lahir karakter sebagai bangsa Indonesia.

Pendidikan seperti apapun sebenarnya membentuk karakter. Untuk itu diperlukan pendidikan yang berimbang antara kognitif, afektif dan psikhomotor. Adalah salah jika kita berpikir akan mencetak karakter peserta didik menurut "kehendak dan cita idiilnya", dengan melupakan faktor lingkungan belajarnya (fisik dan non fisik). Kekeliruannya, karena melupakan pola dan iklim kehidupan nyata peserta didik dalam kehidupannya di sekolah dan atau bersama temannya.

Padahal lingkungan tersebut amat menentukan pembentukan diri peserta didik, karena melalui lingkungan tersebut, peserta didik menyerap nilai dan keyakinan yang dikehendaki masyarakat serta digunakan sebagai kekuatan moral dalam hidupnya.

Kagan (1999) berpendapat, ada sepuluh komponen untuk membangun karakter yang menunjukkan kecerdasan moral, yakni :

1) respect ;2) responsibility; 3) honesty; 4) integrity; 5) justice; 6) citizenship; 7) loyalty; 8) courage; 9) cooperation; dan 10) caring.

Kejujuran menjadi salah satu indikator pencapaian tujuan akhir untuk membentuk " good citizen”, yakni warganegara yang memiliki kecerdasan tidak hanya intellektual, tetapi juga moral. Dan perangkat pedagogis yang terbaik dalam membelajarkan moral adalah melalui pemberdayaan kelas sebagai kelompok sosial.Dan ini memerlukan pemeliharaan secara dinamis dan terus menerus atau berkesinambungan.

Membangun karakter melalui pendidikan, tidak hanya pada tataran konsep tetapi mampu dicerna untuk dapat diaplikasikan dalam kehidupan . Dengan demikian akan tumbuh pribadi yang mandiri yang tidak menggantungkan hidup dari pihak atau individu lain.

Dan ini perlu dilakukan sejak dini. Jika peserta didik, tak dibangun karakternya, maka yang akan menjadi pemimpin di masa depan nanti, adalah individu-individu yang mudah tunduk pada kepentingan-kepentingan individu atau kelompok lain yang memiliki kepentingan ,yang bisa berakibat negatif dan fatal. 
Ada fenomena lain yang cukup mengkhawatirkan, bahwa kaum muda tidak mampu atau tidak berkesempatan untuk menunjukkan entitas dirinya. Seharusnya kaum muda tampil sebagai entitas yang memiliki perspektif konstruktif dalam memandang dunia, sehingga mampu berkontribusi secara signifikan dalam memformat masa depan bangsa dan negara. Kebanyakan kaum muda masa kini terjebak dalam perangkap sistem ijon karena terlalu berpikiran pragmatis, terburu-buru, dan tidak tahan bekerja keras. Pragmatisme yang telah menjerumuskan mereka ke dalam keterkungkungan dan hegemoni pihak-pihak tertentu yang menginginkan mereka menjadi individu-individu yang tergadai budaya dan kehilangan karakternya.

Mencermati hal ini, peran pendidikan membangun karakter perlu dimaksimalkan dan operasionalisasinya tentu menjadi tugas bersama.

Kilpatrick (1992) dan Lickona (1992) sebagai pencetus utama pendidikan karakter percaya adanya keberadaan moral absolute. Mereka meyakini bahwa nilai moral tidak hanya bersifat relatif, tetapi ada nilai moral yang bersifat absolut yang bersumber dari agama apapun di dunia. Moral absolute yang disebut the golden rule ini perlu diajarkan kepada generasi muda agar mereka paham betul mana yang baik dan benar, misalnya dengan menanamkan sikap jujur, suka menolong orang, saling menghormati dan bertanggung jawab.

Kaitannya dengan pendidikan moral, pendidikan karakter mempunyai makna lebih tinggi dari pendidikan moral, karena pendidikan karakter bukan sekadar mengajarkan mana yang benar dan mana yang salah, namun juga menanamkan kebiasaan (habituation) tentang hal yang baik sehingga anak menjadi paham (domain kognitif) tentang mana yang baik dan salah, mampu merasakan (domain afektif) nilai yang baik, lalu dapat melakukannya (domain psikhomotor) (Martianto, dalam http://www.tumoutou.net)

Menjadikan peserta didik yang cerdas di lingkungan yang mengajarkan kebaikan, akan membawa pada pengenalan diri, penguasaan diri, kecintaan pada sesama seperti mencintai diri sendiri.

\section{Bagaimana membina nilai kejujuran di kalangan peserta didik?}

Membina nilai kejujuran dikalangan peserta didik memerlukan keterlibatan Kepala Sekolah, guru, peserta didik dan orang tua. Jika Hobbes (Beck ,1981, 204) memandang nilai kejujuran adalah persoalan etika, maka untuk mencapai kebaikan, seseorang perlu bekerja keras, karena 'dengan kerja keras akan menghapus pikiran ataupun nalar yang sesat'. Maka dalam 
belajar juga diperlukan kerja keras agar nalar sesat hilang berganti dengan kebaikan.

Pembinaan nilai kejujuran di kalangan peserta didik, penulis visualisasikan sebagai berikut:

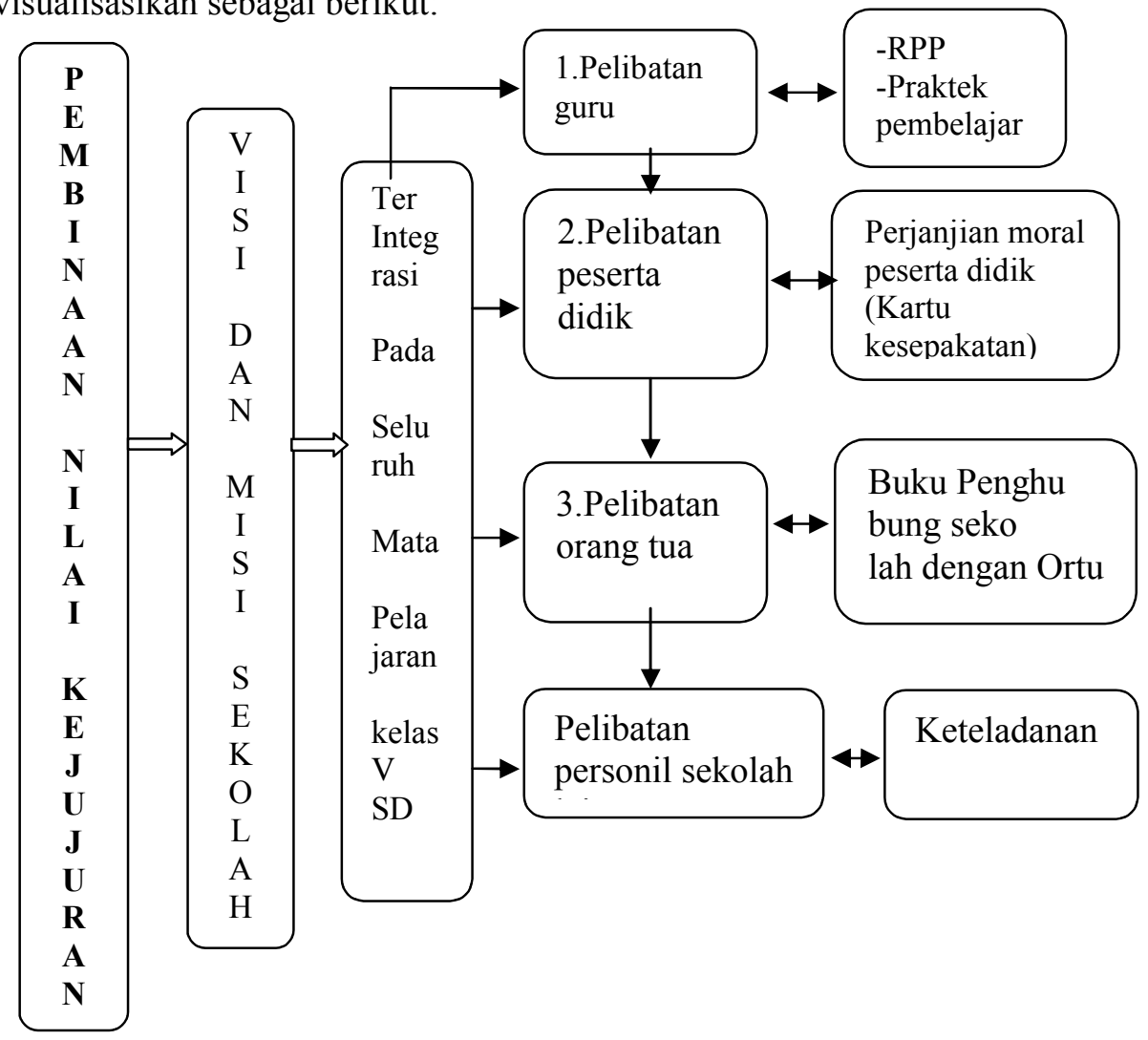

Gambar : 1

Model Pembinaan Nilai Kejujuran, Sebuah Alternatif Pendidikan Karakter di Sekolah (Fadillah, 2011)

Pada lembaga pendidikan formal yakni persekolahan, Kepala Sekolah bertanggung jawab membina nilai kejujuran di kalangan personil sekolah yang dipimpinnya dan diwujudkan pada perumusan visi dan misi sekolah. Visi dan misi ini merupakan tujuan yang akan dicapai sekolah, yang merupakan penjabaran dari tujuan pendidikan nasional, yakni manusia Indonesia yang berakhlak mulia. Karenanya visi dan misi yang dirumuskan 
Kepala Sekolah sudah selayaknya mengandung pesan-pesan moral, yang perlu disosialisasikan pada seluruh personil sekolah agar diketahui serta diwujudkan dalam kehidupan sekolah. Dengan demikian, pesan-pesan moral yang terkandung dalam visi dan misi ini dapat diintegrasikan guru pada semua mata pelajaran yang ada di sekolah. Pengintegrasian visi dan misi ke dalam mata pelajaran yang ada di sekolah menuntut keterlibatan guru dalam membina nilai kejujuran di sekolah agar melekat dan menjadi karakter peserta didik.

Keterlibatan guru dalam membina nilai kejujuran di kalangan peserta didik, yang diintegrasikan pada mata pelajaran, bermula dari perumusan persiapan mengajar berupa RPP, yang memuat tujuan instruksional dan tujuan pengiring. Tujuan instruksional berbicara tentang tujuan setelah pembelajaran berlangsung, dan ini lebih banyak bersifat kognitif, sedangkan tujuan pengiring menghendaki adanya perubahan perilaku peserta didik ke arah yang lebih baik, jadi lebih menyentuh afektif peserta didik. Pengembangan ke duanya hendaknya sejalan, agar dapat membina pribadi peserta didik secara utuh.

Di samping RPP, membina nilai kejujuran juga berlangsung sepanjang praktek pembelajaran, dengan mengindikasi ketidakjujuran peserta didik yang ditangkap guru, ketika pembelajaran berlangsung. Indikasi ini mestinya tertangkap guru, karena sangar besar kemungkinan bahwa peserta didik tidak tahu bahwa perilakunya tidak baik, dan jika ini berlanjut akan tertanam menjadi habit pada diri peserta didik. Untuk menangkap indikasi ketidakjujuran peserta didik, guru dalam pembelajarannya selalu memperhatikan peserta didik, mulai dari mencermati penjelasan guru, mengerjakan soal latihan, mengoreksi soal latihan ataupun memeriksa pekerjaan rumah. Ketika peserta didik mengerjakan soal latihan, guru perlu memperhatikan perilaku peserta didik ketika sedang mengerjakan soal, guna menangkap indikasi ketidakjujuran peserta didik dalam bekerja. Di samping itu, dengan mengamati perilaku peserta didik, guru juga dapat memperhatikan cara peserta didik menyelesaikan soal yang diberikan padanya. Demikian pula dengan mengoreksi soal latihan atau mengoreksi pekerjaan rumah . Ini dapat dilakukan peserta didik, dengan saling tukar antar teman. Sambil membahas soal latihan, guru mencermati perilaku peserta didik ketika mengoreksi soal. Koreksi soal dapat juga dilakukan oleh guru dengan terlebih dulu mengoreksi pekerjaan peserta didik dan mencatat nilai 
yang diperoleh peserta didik, tanpa memberi nilai atau catatan pada pekerjaan peserta didik, yang kemudian dikembalikan pada peserta didik untuk diperiksa ulang oleh peserta didik. Perbedaan nilai antara hasil koreksian guru dengan peserta didik, dapat dikategorikan adanya indikasi yang tidak jujur. Jadi kehadiran guru dalam proses pembelajaran menunjukkan kepedulian guru yang sangat dibutuhkan oleh peserta didik. Hanya guru yang penyayang yang mampu meningkatkan kemampuan penguasaan peserta didik.

Keterlibatan peserta didik terkait oleh perjanjian moral yang dilakukan peserta didik untuk dirinya sendiri dengan cara memilih kartu kesepakatan yang disiapkan guru. Ini dilatarbelakangi pendapat bahwa orang tidak menjadi bijaksana dengan sendirinya, tetapi mereka menjadi bijaksana berkat usahanya sendiri dan masyarakatnya. Dalam rangkaian pengembangan pembinaan nilai kejujuran, agar karakter peserta didik berkembang, maka peserta didik perlu mengenal dirinya dan berusaha untuk meningkatkan perilakunya, dengan menggunakan kartu kesepakatan moral yang dipilih dan dipegang peserta didik, untuk jangka waktu tertentu dan berperilaku tidak menyimpang dari kartu yang dipegangnya. Sehingga kartu ini dapat dikatakan berfungsi sebagai media bagi peserta didik untuk mengambil keputusan moral dan berbuat sesuai dengan keputusan dan diharapkan bahwa perilaku moral peserta didik (moral being) tumbuh dan terjaga serta berlangsung seumur hidup . Ini didasari oleh prinsip moralitas yang memandang bahwa peserta didik mempunyai kemampuan untuk bertanggung jawab. Dengan adanya kartu kesepakatan yang dipegang peserta didik, akan membimbing peserta didik untuk mengenal dirinya. Descartes dengan istilah cogito ergo sum (saya berpikir, karena itu saya ada), juga dapat diartikan pada pengenalan diri.

Bidney (1953) mengakui bahwa hanya manusia yang mempunyai kemampuan untuk bersikap obyektif terhadap dirinya sendiri, berada terpisah dari dirinya sendiri dan berpikir seperti apa dirinya dan apa yang ingin dilakukannya dan hendak menjadi apa (Burns, 1979,4). Jadi dengan memegang kartu kesepakatan, mengantar peserta didik berjanji pada diri dan mengenal dirinya. Penyimpangan terhadap kartu kesepakatan tersebut, dapat diartikan sebagai munculnya perilaku negatif. Kilpatrick menyebutkan salah satu penyebab ketidakmampuan seseorang berlaku baik meskipun ia telah memiliki pengetahuan tentang kebaikan itu (moral knowing) adalah karena ia 
tidak terlatih untuk melakukan kebaikan (moral doing). Berangkat dari pemikiran ini, maka kesuksesan pembinaan nilai kejujuran melalui mata pelajaran yang ada di sekolah, sangat tergantung pada ada tidaknya knowing, loving, dan doing atau acting dalam pembinaan nilai kejujuran.

Penilaian yang diberikan pada perilaku peserta didik yang negatif bukan bermaksud untuk memvonis peserta didik, tetapi bertujuan untuk membinanya. Dan guru dituntut untuk selalu berpikir terbuka bahwa perilaku negatif yang dimiliki peserta didik pada saat itu tidaklah bersifat permanen artinya perilaku tersebut masih mungkin dan selalu berubah-ubah, sehingga memerlukan pembinaan yang terus menerus.

Adapun kartu kesepakatan yang dikenalkan pada peserta didik berupa pernyataan-pernyataan yang ditulis guru di kartu, dicontohkan sebagai berikut:

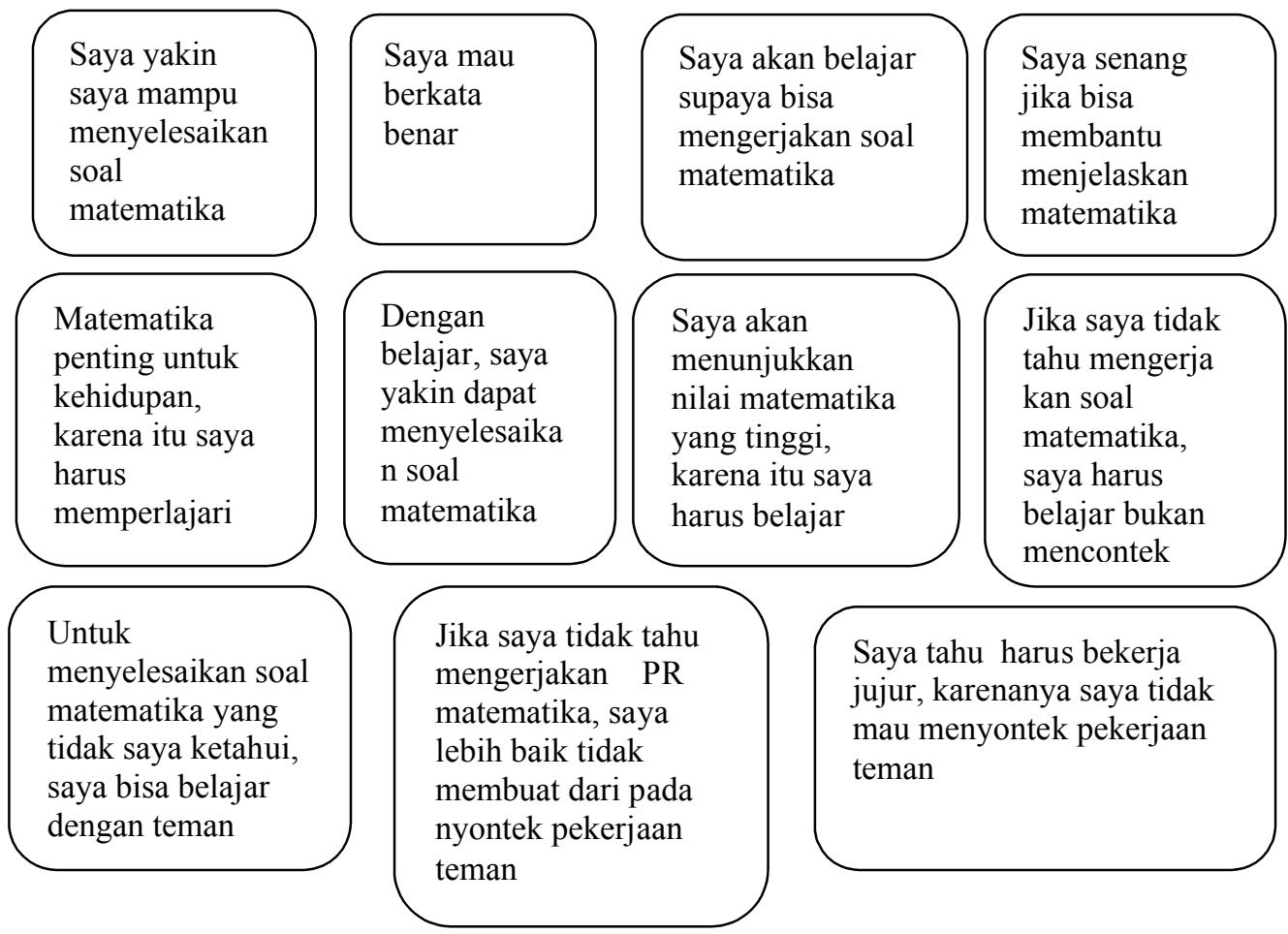


Di samping perjanjian moral yang dilakukan peserta didik, keterlibatan peserta didik juga dilakukan dengan menelusuri kejujuran peserta didik, yang dinilai dari perkataan, sikap dan perbuatan.

Penelusuran dari perkataan dijaring dari penalaran peserta didik terhadap pelajaran matematika ( menyangkut moral knowing dan moral feeling).

Ketidak berdayaan peserta didik menguasai materi pelajaran matematika, bukan hanya bersumber dari diri peserta didik tetapi masih ada sebab lainnya berupa kurangnya interaksi dialogis antara guru dan peserta didik, yang menyebabkan peserta didik tidak terbuka tentang ketidaktahuannya terhadap pelajaran matematika.

Dalam kaitan dengan membina nilai kejujuran, yang berarti membangun unsur afeksi peserta didik, maka kemandirian belajar pada diri peserta didik, perlu dipupuk menuju karakter yang positif.

Kejujuran peserta didik dalam perbuatan atau pengamalan, dibina dengan menggunakan buku penghubung antara sekolah dan orang tua.

Keterlibatan orang tua, dilihat dari kesediaan orang tua untuk menilai perilaku anaknya dengan mengisi buku penghubung. Keterbukaan ini mensiratkan adanya kepedulian orang tua untuk memperhatikan anaknya. Buku penghubung ini tidak hanya diisi oleh orang tua, tetapi juga oleh guru, agar guru maupun orang tua secara bersama berkepentingan memperhatikan perilaku peserta didik.

Adapun contoh buku penghubung yang dikirim ke orang tua dan guru seperti berikut:

\section{BUKU PENGHUBUNG SEKOLAH DENGAN ORANG TUA} (Buku Pegangan Orang Tua / Guru )

I.Identitas Peserta Didik

1. Nama Peserta didik

2. Tempat dan tanggal lahir

3. Nama Ayah kandung

4. Nama Ibu kandung

5. Anak ke

6. Jumlah saudara kandung :

7. Pekerjaan Ayah

8. Pekerjaan Ibu 
II. Isi Kartu Yang Dipegang :

III . Catatan Peristiwa

\begin{tabular}{|l|l|c|}
\hline Hari, tgl & \multicolumn{1}{|c|}{$\begin{array}{c}\text { Perilaku keseharian peserta didik di rumah / di } \\
\text { sekolah }\end{array}$} & $\begin{array}{c}\text { Tanda } \\
\text { checklist }\end{array}$ \\
\hline & Perilaku yang berbohong & \\
\hline & Perilaku yang curang & \\
\hline & Perilaku yang dapat dipercaya & \\
\hline & Perilaku yang tulus & \\
\hline & Perilaku yang ikhlas & \\
\hline & Perilaku yang berkata benar & \\
\hline & Perilaku yang berbuat benar & \\
\hline & Perilaku yang taat tatib sekolah & \\
\hline & Perilaku yang memuliakan orang yang diajak bicara & \\
\hline & Perilaku yang lemah lembut dalam ucapan & \\
\hline
\end{tabular}

\section{Kesimpulan}

Secara umum, dapat dikatakan bahwa kejujuran adalah salah satu pendongkrak pendidikan karakter. Karenanya menjadi tanggung jawab semua pihak, orang tua, sekolah, masyarakat, pemerintah. Di sekolah, pendidikan karakter dalam bentuk pendidikan nilai diintegrasikan dalam semua mata pelajaran. Pengintegrasian pendidikan nilai pada mata pelajaran, menuntut kepedulian serta keprofesionalan guru untuk melaksanakannya, namun kenyataan guru belum disiapkan untuk mengeksplisitkannya dalam mata pelajaran.

Oleh karena itu, perlu adanya pelatihan pendidikan karakter untuk guru, agar guru dapat mengeksplisitkannya dalam pembelajaran di kelas, dengan mengintegrasikannya pada mata pelajaran.

\section{Daftar Pustaka}

Antonio, M.S., (2007), Muhammad SAW, The Super Leader Super , Jakarta, Tazkia Multimedia.

Aristoteles, (1998), Nicomachean Ethics, (terjemahan), Jakarta, Penerbit Teraju (PT Mizan Publika).

Asri Budiningsih, (2004) , Pembelajaran Moral, Berpijak pada karakteristik peserta didik dan budayanya, Jakarta, PT Rineka Cipta. 
Beck Clive M., (1981), The Reflective Approach to Values Education, edited by Johan F. Soltis, Philosophy and Education, Chicago Illinois, The University of Chicago Press

Dewey, John, (1975) , Moral Principles In Education, London and Amsterdam, Southern Illinois University Press Carbondale and Edwardsville.

Hersh,R.H., Miller, J.P., Fielding, G.D.,(1980), Models of Moral Education, New York, An Appraisal, Longman Inc

Kagan (1999), Higher-Level Thinking Questions for Developing Character, Calle Cordillera, San Clemente

Kawangmani, Soleman, M.Div., (2008), Pembinaan Global Persekutuan Maha peserta didik Kristen Surakarta, Alethia Edisi 02, Tahun II

Michele Borba, (2001), Building Moral Intelligence, The Seven Essential Virtues That Teach Kids to Do the Right Thing, Alih bahasa Lina Jusuf, (2008), Jakarta, Gramedia Pustaka Utama.

Mujib A, ( 2001), Nuansa-Nuansa Psikologi Islam, Cetakan I; Jakarta, PT Raja Grafindo Persada.

Mulyana, R., (2004) , Mengartikulasi Pendidikan Nilai, Bandung, Penerbit Alfabeta

Undang-Undang.No.20 Tahun 2003 tentang Sistem Pendidikan Nasional. Jakarta

Winecoff, H.L., (1988), Values and Education : Concepts and Models; Hand Out Perkuliahan Pendidikan Nilai pada prodi Pendidikan Umum S 3 Bandung, PPS UPI

Zuriah, Nurul, ( 2007 ), Pendidikan Moral dan Budi Pekerti, dalam perspektif perubahan,menggagas platfom Pendidikan Budi Pekerti secara kontekstual dan futuristik, Jakarta, Bumi Aksara. 